\title{
Taking a Look into the Culture Shock Experienced by Foreigners at Rumbai, Pekanbaru
}

\author{
Herdi Herdi and Titi Handayani \\ Universitas Lancang Kuning, Pekanbaru, Indonesia \\ thandayanizamili@gmail.com
}

\author{
ARTICLE HISTORY \\ Received : 15 August 2020 \\ Revised : 24 August 2020 \\ Accepted : 27 September 2020
}

\section{KEYWORDS}

Culture Shock

Foreigners

Language in Culture

\begin{abstract}
Culture is something that represents a country's existence. Every country has a different culture because it has its way of life, habit, and custom. This research was aimed to find out the culture shock experienced by foreigners at Rumbai, Pekanbaru. This research was categorised as survey research designed. This research was descriptive qualitative. This research used purposive sampling to get the sample. Three foreigners responded in this research. The data of the study were taken by using observation, interview and field note. The researcher found that there were four stages of culture shock experienced by foreigners and six factors affecting culture shock experienced by foreigners. The first stage of culture shock was euphoria/honeymoon phase because of hospitality, scenery and custom of the host country. The second was the crisis stage, this crisis phase because of cross-culture differences in how people communicate. The third was recovery phases, where they began to accept, to resolve and to adjust their cultural differences. Finally, was the adjustment phase where they were enjoyed and accepted the cultural differences in the new environment. There were six factors affecting culture shock, and they were culture shock on weather, culture shock on food, culture shock on language, culture shock on social life, culture shock on etiquette and culture shock on the dress.
\end{abstract}

\section{Introduction}

Culture has an essential part of human life since it becomes a part of the way to be acceptable in society. Therefore, learning culture is necessary to respect other people's lives by looking at their representations in visual, textual, and auditory media (Saragi et al., 2020). That means that culture helps us to know what we can do as individuals and what our responsibilities are as members of the group (Derin et al., 2020). Therefore language and culture are intricately related. Language is formed by culture, and culture is influenced and impacted by languages (Amin, 2020; Lauren \& Derin, 2020). Crosscultural understanding is concerned with understanding people from different cultural backgrounds and relating to the culture of a people so we can construct our attitudes and world view, more tolerable and generous toward strange ways that may be shown by another citizen of another country.

Cross-cultural differences also happen to foreigners who come to Pekanbaru. As we know that Pekanbaru is the Capital Indonesia province of Riau, which is inhabited by foreigners, cross-cultural misunderstanding will arise if a person from another culture misinterprets a complicated situation and condition that happen when it has a different meaning across cultures. The foreigner must experience culture shock because they have different cultures, principles, ways of thinking and also different ways of communicating with other people. Since it is very predictable that when people arrive in a foreign country, they find themselves in a different culture and have to adjust to a new environment. They will face a lot of different things such as how to dress, behave, and talk as well as adjusting to different weather, food, language and values. The incident is called culture shock.

Indonesia is a place where we are born, work, live, and might even be our last place on earth. However, it's quite different from some people who come to Indonesia for the first time. People travel overseas for many purposes, including education, work, business networking, and even for vocation. They must be ready and have enough awareness about new situations of their destination.

Culture shock can be a bad condition when it involves things in between trouble sleeping, feeling uncomfortable, and or depression. The study of culture shock is quite needed because of globalisation. Also, culture shock experienced by a person who comes from overseas or outside the region, especially seeing Indonesia, which has diverse cultures and exciting sights.

Moreover, some research has proved their researchers dealing with culture shock. Firstly, a researcher conducted by Prasadhya (2012) which entitled "An Analysis of Culture Shock face by 60th-61th PIBBI Students" the researcher found six kinds of problems that was faced by the PIBBI students, they are: the first food was the biggest problem, the different characteristic of food make the 
subject got shocked and sick. The second is language; seven of fourteen respondents mention that it was challenging to understand the Indonesian language. The third is pollution and environment condition, and foreigners said that here is more polluted and they feels irritated because of rubbish everywhere. The fourth transportation and climate, most of them stated that they felt annoyed with the way of Indonesian people drove on the road. The last were people and value, the way of local people greet, talks, acts and the value of privacy religiosity and communication style very different that brings to misperception and misunderstanding between each other.

Secondly, there is a research conducted by Poedjiastutie (2009) entitled "Culture Shock Experienced by Foreign Students Studying at Indonesian University" the research study was designed to examine the potential culture shock experienced by foreign students in an Indonesian university. Ten foreign students' responded to the questionnaires sent by the writer through BIPA (Indonesian for foreigners) in the international office of foreign students universities. It was found that three points of academic life make foreign students' experience culture shock, namely: teacher s roles and attitudes, many respondents complained that some Indonesian teachers in their course did not attend to the classes with apparent reason. The local students' attitudes, foreign students' wanted to listen attentively on that lecture, but they were distracted by the noises made by some local students. Also, many local students might comment rudely on the foreign students' existence as if the foreign students' were strange creature; poorly organised programs, there were no clear and specific information about where to get books and references, when the tests are given and conducted, and when the assignment was due. Besides, there was no clear schedule, subject descriptions, and syllabus, rules and regulations. In social life, it was found that foreign students' experienced culture shock in 3 aspects, namely: women-men relationships; different ways of thinking and different habits.

The last, Peter (2012) conducted the research entitled "The Effect of Culture Shock on English Language Learning of Foreign students' in India: A Study at the Tertiary Level. This research study compared the effects of the three psychological factors- culture shock, personality traits and motivation on English language learning" One of the limitations of this study is that it did not take into account linguistic and social factors. Another is that due to lack of time, more number of colleges could not be covered. These drawbacks may be remedied by further research in this field.

\section{Method}

\subsection{Research Design}

This research was conducted by using descriptive qualitative research. The researcher collected the data about individual life's, such as her/his experiences culture shock and discussed those experiences.

\subsection{The setting of the Research}

The research was conducted in May 2018 at Rumbai, Pekanbaru.

\subsection{Informant}

In this research, the research used purposive sampling and chose three foreigners who live at Rumbai, Pekanbaru. Based on the interview with the foreigners, they said they could speak English and Indonesian. So the researcher selected Ms. Susan, Mr. Najaballah and Mr. Tedd as the informant of this research.

\subsection{Instruments}

The instruments used in this research were observation, interview and field note. First observation, it was used to describe the setting, behaviour, and interaction during the interview. The second instrument was the interview, and it was used to get the data about the informants' stories and experiences. The researcher interviewed by using a set of questions. The third instrument was field note. This instrument has been applied to get the information during the researcher conduct. It has been used to collect additional data observed by the researcher. In this case, the researcher, as the observer has made notes about everything that got from the foreigners.

\section{Results}

\subsection{Findings}

This study has done the original record to the foreigners at Rumbai Pekanbaru on May to find out the culture shock experienced by foreigners. The interview has been given to answer the questions of this study. The questions were "How is the culture shock experienced by a foreigner during their stay in Pekanbaru city? And what factors make foreigners kind of new culture which are shocking them?" to answer to find how the culture shock experienced by the foreigner, the researcher interviewed with the foreigners. Furthermore, the researcher did observation and made a field note to find out how was their characters during the interview.

Ward (2001) states that the process of adaptation consists of four phases: initial euphoria / honeymoon, disaster, recovery and adaptation phase. In addition, the principle includes positive and negative effects. The theory of the change is based on the theory of Ward.

The first stage was the Initial Euphoria/ Honeymoon. This phase was first experienced by foreigners in the new environment. At this time, foreigners felt happy and enjoyed the new location they visited. Foreigners had no new environment problems whatsoever. Based on the interview with foreigners, this study found some important facts that make foreigners feel euphoria or honeymoon 
because of the hospitality, the results, and the interview showed it to be in the positive effects of a cultural shock.

The second stage was the Crisis. This phase is the negative effect foreigners experienced when their own country became different from the new country. The difference between the old and new cultures is shown in this point. Some participants were interviewed in a new environment that upset, confused and frustrated foreigners.

The third stage was the Recovery. This phase showed that someone tried to understand and adapt to new environment patterns, tried to find the way to communicate and to stay in a new environment. The individual began to solve and learn about the culture of differences in the host culture in this point. Some participants were interviewed about something that helped the foreigner to adapt and interact in the new environment with people.

The fourth was the Adjustment. In this final phase, people will adapt and learn all in a new setting without feeling anxious, depressed and confused again.

\subsection{Discussion}

The researchers started to explore the cultural shock processes and the consequences of cultural shock faced by foreigners in Rumbai, Pekanbaru which consist of four stages such as Honeymoon, Crisis, Recovery and Adjustment in connection with the review of this report.

The first is the Honeymoon phase. People who join a new culture are like those who come for luncheons, holidays or company to other groups. When a first person visits a new environment, they will feel excited, beautiful and happy with everything they encounter in a new culture and will love the facilities, beautiful landscapes and good infrastructure. If people first arrive in a new environment or country, they will feel happy, beautiful and excited with all their new experiences.

Based on the finding above, the researcher found that there were three kinds of the honeymoon phase, indicating that foreigners experienced this phase when they entered Pekanbaru for the first time. The first is hospitality. The hospitality of Pekanbaru people was made the foreigners amazement and happy for the first time they came in Pekanbaru city, most of them said Indonesian people are kind and friendly, and helpful. It appeared that foreigner 1 one said Pekanbaru People more helpful and kind. The foreigner 2 showed that he is happy here because, during the stay where nobody bothers them, and he did not have any problem, he had many friends. The second is the scenery. Based on the result, the researcher inferred that scenery were included in the honeymoon phase. They feel they wondered to see the beautiful sight In Pekanbaru city, and it showed by foreigner 3, he said Pekanbaru is clean, not much Rubbish. The next is the entertainment in Pekanbaru, it showed by foreigner 1 when she went outside she saw men with the monkey, and the monkey did tricks, she was happy when she watched this. The last is driving.
Based on the result of interviewed, the researchers inferred that driving in Pekanbaru more easy no a lot of traffic, so it is much better. It showed by foreigner 1 and 3 .

The second phase is the Crisis phase. This phase is the stage of culture shock where experiences unknown and negative aspects. The differences might come from some aspects of interaction with the host country that include cross-cultural differences in how people communicate. When a person from two different cultures meets, they will have difficulty in communicating with the one another to the extent that their perspective's codes differ. Everything which is found in the new place was horrible because they were still not used to the new environment and met with people whom they were not familiar every day. The differences might become from some aspects of interaction with the host of the country that includes cross-cultural differences in how people communicate. From the finding above, some problems become the crisis phase. The first is etiquette and local people attitude. The foreigner 1 indicated the etiquette of personal space. She was shocked when someone stands very close to her without giving enough space to her because, in her country, one called personal space. The term personal space generally refers to the physical distance between two people in a social, family, or work environment. Another problem is about the question, and she also felt surprised when someone asked something that can not ask in her home country. Also, foreigner one felt how local attitude treat her when she buys something at tradition market, and she got the price more expensive. The second problem is the language. Language is a very important element in the connection and close relationship with others with whom we come in contact. When you are in a new culture, language barriers are a major problem for foreigners. They were depressed and homesick due to lack of language, and it caused them to feel isolated in their new environment. The foreigners faced the difficulty with communicating with the host of the country it was experienced by all the foreigners interviewed. The third is the way of wearing a dress. The different country showed different dress, for example, the informal dress that is acceptable in one culture but it may be considered as impolite in the other culture. The forth is the weather. Most of the foreigner confused with the weather in Pekanbaru city. Because of the weather in Pekanbaru so hot different from their weather that so cold. It showed by foreigner 2 and 3. They said the weather in Pekanbaru city is a little hot. The fifth problem is the food. In each culture, people may prefer certain foods, food preparation methods. Foreigner as sojourners will eat different food in the host country. It represented by all of the foreigners have been interviewed, they felt the foods in Pekanbaru is so spicy it's so difficult for them for the first time. The next problem is social live different, social shock experienced by a foreigner was also revealed. Social life covered broad aspects but only experienced came from foreigner 2. In this study, the social shocks was when foreigner 2 saw everybody can have a relationship, 
otherwise in his country. Also, live apart from family, most of the foreigners very miss their family. The last is physical appearance. Physical appearance leads to a person's physical feature. The researcher found one data about different physical appearance. It was showed by foreigner 1. She was shocked for the first time she has known she is huge than other of his country in the United States.

The third phase is the recovery phase. Recovery is a stage where persons try to understand and try to adapt the habits to a new environment, and then try to find out the solution to be able to interact and to stay in a new environment. Based on the statement above, the researcher found that there were six crisis resolution and culture learning new that the foreigners began to solved and learned about the differences culture in the host culture such as language, clothes, weather and food. The researcher found resolution and culture learning was experienced by foreigners to heel their problem. The first problem is language but can solve it by learning the language in the host country. It was experienced by foreigner 1, 2 and 3 . They tried to learn the language. The second is the way of wearing a dress. Some foreigner have no problem with the way in wearing the dress in Pekanbaru, but it is very different from the foreigner 3 when he saw someone used sandals with stock, he felt it was strange. After he found it someone often wear it, then he felt not strange anymore. The third is food. In food problem, some foreigner begins to adapt with difficulties facing the different food in the host country. It represented by foreigner 1 . They began to find out how to make and tested any food in the host country. The last is physical appearance. In each country may have different ethnic; for example, in America, most people have white skin different from Africa, most of the people in Africa have black skin. Like in Pekanbaru city as we know most people have a small body. It was made the foreigner 1 understand the different physical appearance in Pekanbaru and United State. After analysing the data, the writer concludes that all of the foreigners experienced recovery phase. They become to accept, to resolve and to adjust their cultural differences by crisis resolution and culture learning.

The last is an adjustment. Talking about the adjustment phase, foreigners can enjoy and accept their majorities problems. Adjusting to the new environment would be easy when foreigners know the language in the host country. The foreigner can interact and enjoy communicating with the others in the host country because they have known a little bit of Indonesian language. It was shown by all of the foreigners. They were comfortable because they can interact with the host country. The way in wearing the dress, during the stay in Pekanbaru, foreigners have been habitual to seeing people used sandals and stocks, it was represented by foreigner 3 . Then adjust with the weather. Foreigner has been habitual with the weather in the host country. It was represented by foreigner 1 and 2 . They were not too much difficulty with the weather because it was as usual for them and feel comfortable. They also can adjust to the food. The foreigners was accustomed and enjoyed with the tested food, especially spicy food, even they began to like and enjoyed the food in the host country. It was showed by foreigner 2 and 3, and they had been enjoyed the food in the host country. After the foreigner one feels huge than other, the foreigner has been understanding and habitually with the physical appearance in Pekanbaru city. It was showed by foreigner 1 . She has been usual with the physical appearance of Pekanbaru's people that most of them have a small body.

After analysing all the data, the researcher concludes that adjustment phase as the last stage makes the foreigners reflect enjoyment, and it was experienced by all foreigners as the participant in this research, where they enjoyed and accepted the cultural differences in Pekanbaru as a new environment. These finding appropriate with Ward's theory that explained there are four phases of culture shock.

From all of the data above, the writer concluded that the effects of culture shock appeared through the phases of culture shock. Honeymoon phase contains the positive effects, and the crisis phase contains negative effects, recovery and adjustment phase also brings positive effects to the foreigners in Rumbai, Pekanbaru.

\section{Conclusion}

Based on the findings and discussion of the previous chapter, the result of this research can be concluded that the informants had been experienced culture shock. These were culture shock on weather, food, language, social life, etiquette, and dress.

\section{References}

Amin, A. (2020). Attitude Towards Language in Sociolinguistics Settings: A Brief Overview. REiLA : Journal of Research and Innovation in Language, 2(1), 27-30. https://doi.org/10.31849/reila.v2i1.3758

Derin, T., Nursafira, M. S., Yudar, R. S., Gowasa, N. S., \& Hamuddin, B. (2020). Persuasive Communication: What Do Existing Literature Tells Us About Persuasive Communication Among Students?. Utamax: Journal of Ultimate Research and Trends in Education, 2(1), 12-18.

Peter, A. S. (2012). The effect of culture shock on English language Learning of international students in India: a study at the tertiary level.

Saragi, V., Septiani, A., \& Jumiati, J. (2020). Seeing the Media Education from the Lens of Critical Discourse Analysis. Elsya : Journal of English Language Studies, 2(1), 27-31. https://doi.org/10.31849/elsya.v2i1.3625 
Poedjiastutie, D. (2012). Culture Shock Experienced by Foreign Students Studying at Indonesian University. Jurnal Humanity, 4(2).

Lauren, C., \& Derin, T. (2020). Systematic Review: Where is Current Research on Conversational Analysis?. Elsya : Journal of English Language Studies, 2(2), 12-17. https://doi.org/10.31849/elsya.v2i2.3879

Prasadhya, I. (2012). “An Analysis of Culture Shock face by 60th-61th PIBBI Students. English Department Faculty Of Language And Literature Satya Wacana Christian University Salatiga

Ward, C., Bochner, S., \& Furnham, A., (2001). The Psychology of culture shock, 2nd Edition. Philadelphia, PA: Routledge 